\title{
Pengembalian Kerugian Negara Akibat Penyalahgunaan Wewenang Terhadap Pengelolaan Keuangan Daerah
}

\author{
Fitria, Ridham Priskap, Afif Syarif \\ Fakultas Hukum, Universitas Jambi, Indonesia
}

\begin{abstract}
ABSTRAK
Penelitian ini bertujuan: 1.Untuk mengetahui, menganalisis bagaimana bentuk penyalahgunaan wewenang dalam hukum administrasi yang mengakibatkan kerugian Negara, 2.Untuk menganalisis pengaturan kerugian negara terhadap pengelolaan keuangan daerah. Penelitian ini menggunakan metode yuridis normatif yang mengkaji halhal yang bersifat teoritis: prinsip, konsepsi, doktrin hukum serta isi kaedah hukum yang berhubungan dengan pengembalian kerugian negara akibat penyalahgunaan wewenang terhadap pengelolaan keuangan daerah. Adapun pendekatan penelitian yang digunakan adalah pendekatan konseptual, pendekatan perundang-undangan dan pendekatan sejarah. Penganalisisan juga dilakukan dengan cara interpretasi, evaluasi dan menilai bagaimana pengaturan pengembalian kerugian negara dilihat dari beberapa penerapan hukum. dapat mengakibatkan terjadinya kerugian negara/daerah yang juga disebabkan oleh penyalahgunaan wewenang terhadap pengelolaan keuangan daerah tersebut. Hasil penelitian menunjukkan bahwa jika terjadi kerugian Negara/Daerah akibat penyalahgunaan wewenang terhadap pengelolaan keuangan daerah haruslah dikembalikan dan dipulihkan oleh pihak yang melakukan pelanggaran tersebut berdasarkan peraturan perundang-undangan yang berkaitan dengan pengembalian kerugian Negara/Daerah yang dapat dilakukan melalui prosedur hukum administrasi. Pengembalian kerugian Negara/Daerah terhadap bendahara ditetapkan oleh BPK (Badan Pemeriksa Keuangan), sedangkan pengembalian kerugian Negara/Daerah terhadap pegawai negeri bukan bendahara ditetapkan oleh Menteri/Pimpinan Lembaga/Gubernur/Bupati/Walikota. Rekomendasi penelitian ini adalah diharapkan pengaturan mengenai pengembalian kerugian Negara akibat penyalahgunaan wewenang dalam pengelolaan keuangan daerah lebih dipertegas dan Pemerintah segera membuat ketentuan yang konkrit mengenai prosedur pengembalian kerugian negara terhadap bendahara dan pegawai negeri bukan bendahara dan Pejabat lain agar terjadi sinkronisasi terhadap peraturan perundang-undangan pengembalian kerugian Negara/Daerah tersebut.
\end{abstract}

Kata Kunci: Pengembalian, Kerugian Negara, Penyalahgunaan Wewenang

\section{PENDAHULUAN}

Pengelolaan keuangan negara merupakan bagian dari pelaksanaan pemerintahan negara. Pengelolaan keuangan negara adalah keseluruhan kegiatan pejabta pengelola keuangan negara sesuai dengan kedudukan dan kewenangannya, meliputi perencanaan, pelaksanaan, pengawasan, dan pertanggungjawaban. Jadi ruang lingkup pengelolaan keuangan negara meliputi:

1) Perencanaan keuangan negara;

2) Pelaksanaan Keuangan negara;

3) Pengawasan keuangan negara;

4) Pertanggungjawaban keuangan negara. ${ }^{\mathrm{i}}$

Pengelolaan keuangan pemerintah daerah di Indonesia terkait dengan kekuasaan atau kewenangan yang dimiliki oleh kepala daerah sebagai pemimpin pemerintahan daerah. Ketentuan yuridis tentang kekuasaan pengelolaan keuangan pada pemerintah daerah dapat dilihat dari beberapa peraturan yang mengatur tentang keuangan Negara yang sekaligus terkait dengan pemerintah daerah.

Pemegang Kekuasaan keuangan Daerah berdasarkan Pasal 283 Undang-Undang 23 tahun 2014 Tentang Pemerintahan Daerah:

Pengelolaan Keuangan Daerah merupakan bagian yang tidak terpisahkan dari penyelenggaraan Urusan Pemerintahan yang meliputi kewenganan daerah sebagai akibat penyerahan urusan Pemerintahan. 
Pengelolaan Keuangan Daerah sebagaimana dimaksud pada ayat (1) dilakukan secara tertib, taat pada ketentuan peraturan perundang-undangan, efisien, ekonomis, efektif, transparan, dan bertanggung jawab dengan memperhatikan rasa keadilan, kepatutan dan manfaat untuk masyarakat.

Pasal 284 yaitu:

1) Kepala Daerah adalah pemegang kekuasaan pengelolaan keuangan daerah dan mewakili pemerintah daerah dalam kepemilikan kekayaan daerah yang dipisahkan.

2) Dalam melaksanakan kekuasaan sebagaimana dimaksud ayat (1), kepala daerah melimpahkan sebagaian atau seluruh kekuasaanya yang berupa perencanaan, pelaksanaan, penatausahaan, pelaporan dan pertanggungjawaban serta pengawasan keuangan daerah kepada pejabat perangkat daerah

3) Pelimpahan sebagaian atau seluruh kekuasaan sebagaimana dimaksud pada ayat (2) didasarkan pada prinsip pemisahan kewenangan antara yang memerintah, menguji dan menerima atau mengeluarkan uang.

Ketentuan Pasal dalam Undang-Undang ini menekankan bahwa yang memiliki kekuasaan dalam pengelolaan keuangan daerah adalah Kepala- Daerah selaku pemimpin pemerintahan daerah. Dalam hal ini Kepala- daerah dapat melimpahkan kepada pejabat lain berdasarkan prinsip pemisahan kekuasaan. Dalam hal keabsahan tindakan pemerintahan yaitu meliputi: kewenangan, prosedur dan substansi. (1) kewenangan diperoleh melalui tiga sumber, yaitu atribusi, delegasi dan mandat. Atribusi merupakan kewenangan yang diperoleh melalui pemberian kekuasaan oleh undang-undang dasar, atau merupakan kewenangan yang diperoleh bersamaan dengan pembentukan lembaga atau badan yang bersangkutan. Sedangkan delegasi dan mandat adalah kewenangan yang berasal dari pelimpahan, bedanya pada mandat pelimpahan melalui hubungan atasan dan bawahan, sedangkan delegasi pelimpahan melalui organ pemerintahan kepada organ lain dengan peraturan perundang-undangan. (2) Prosedur bertumpu pada tiga landasan utama hukum administrasi, yaitu asas Negara hukum, asas demokrasi dan asas instrumenal.(3) substansial pada kekuasaan pemerintahan berisi wewenang pengaturan dan pengendalian kehidupan masyarakat dengan dibatasi secara substansi. Aspek substansial menyangkut "apa" dan "untuk apa". Cacat substansial menyangkut "apa" merupakan tindakan sewenang-wenang, sedangkan yang menyangkut 'untuk apa" merupakan tindakan penyalahgunaan wewenang. ${ }^{\text {ii }}$

Isu hukum dari pengawasan adalah implikasi yuridis apabila ditemukan penyimpangan pengelolaan keuangan melalui pengawasan, isu sentralnya digunakan untuk menyelesaikan pelanggaran hukum jika instrumen hukum yang lain telah digunakan tidak memberi kepuasan.

BPK mempunyai tugas melaksanakan pemeriksaan atas pengelolaan dan tanggung jawab keuangan Negara. Berdasarkan ketentuan Pasal 3 Undang-Undang Nomor 15 Tahun 2004 tentang Pemeriksaan Pengelolaan dan tanggung jawab pengelolaan keuangan Negara bahwa obyek pemeriksaan BPK meliputi seluruh unsure Keuangan Negara sebagaimana dimaksud dalam pasal 2 Undang-Undang Nomor 17 tahun 2003. Sedangkan dilihat dari subyeknya, pihak yang diperiksa adalah pengelola keuangan Negara sebagaimana dimaksud dalam ketentuan Pasal 6 ayat (1) Undang-Undang 15 Tahun 2006 tentang Badan Pemeriksaan Keuangan yaitu: BPK bertugas memeriksa pengelolaan dan tanggung jawab keuangan Negara yang dilakukan oleh Pemerintah pusat, Pemerintah Daerah, lembaga Negara lainnya, Bank Indonesia, badan usaha milik Negara, Badan Layanan Umum, badan Usaha Milik daerah, dan lembaga atau badan lain yang mengelola keuangan Negara. ${ }^{\text {ii }}$

Siklus pemeriksaan BPK meliputi perencanaan, pelaksanaan dan pelaporan pemeriksaan, serta pemantauan atas pelaksanaan tindak lanjut hasil pemeriksaan. Dalam Pasal 16 UndangUndang Nomor 15 Tahun 2004 tentang Pemeriksaan Pengelolaan dan Tanggung Jawab Pengelolaan Negara mengatur bahwa: Laporan hasil pemeriksaan atas laporan keuangan 
pemerintah memuat temuan, kesimpulan dan rekomendasi. Laporan hasil pemeriksaan dengan tujuan tertentu memuat kesimpulan. Laporan hasil pemeriksaan memuat dan melampirkan tanggapan pejabat pemerintah yang bertanggung jawab atas temuan, kesimpulan, dan rekomendasi pemeriksa. ${ }^{\text {iv }}$

Pengelolaan keuangan negara yang tidak sesuai dengan ketentuan yang berlaku dapat mengakibatkan terjadinya kerugian negara. Untuk mengatasi terjadinya hal tersebut, dalam Undang-Undang tersebut ditegaskan bahwa setiap kerugian negara/daerah yang disebabkan oleh tindakan melanggar hukum atau kelalaian seseorang harus diganti oleh pihak yang bersalah. Dengan demikian, kerugian negara/daerah yang telah terjadi dapat dipulihkan kembali.

Dalam Pasal 23 ayat (2) Undang-undang Nomor 15 Tahun 2004 tentang Perbendaharaan Negara, BPK memantau penyelesaian pengenaan ganti kerugian negara/daerah terhadap pegawai negeri bukan bendahara dan/atau pejabat lain pada kementerian negara/lembaga/pemerintah daerah. Ketentuan ini diperluas sehingga kewenangan BPK untuk memantau penyelesaian ganti kerugian negara/daerah tidak hanya terhadap pegawai negeri bukan bendahara dan/atau pejabat lain pada kementerian negara/lembaga/pemerintah daerah, akan tetapi mencakup juga memantau penyelesaian ganti kerugian negara/daerah terhadap pegawai negeri bendahara dan pengelola badan usaha milik negara (BUMN). Ketentuan ini diperlukan agar ada pihak ekstern yang melakukan pemantauan atas semua kerugian negara yang terjadi dan tingkat penyelesaiannya, sehingga penyelesaian kerugian negara dapat lebih efektif.

Adrian Sutedi berpendapat bahwa: Pasal 2 Undang-Undang Nomor 17 tahun 2003 yang merumuskan secara lengkap keuangan Negara cenderung menimbulkan kerugian Negara dan membangkrutkan Negara. Hal ini khususnya ditujukan pada Pasal 2 huruf I Undang-Undang Nomor 17 Tahun 2003, yang menyatakan bahwa salah satu arti keuangan Negara adalah kekayaan pihak lain yang memperoleh dengan menggunakan fasilitas yang diberikan pemerintah. Dengan rumusan ketentuan tersebut, Negara akan turut bertanggung jawab terhadap kekayaan pihak swasta yang memperoleh fasilitas pemerintah. ${ }^{\mathrm{V}}$

Berdasarkan Pasal 20 UU Nomor 30 Tahun 2014, maka pengawasan dan penyelidikan terhadap dugaan penyalahgunaan wewenang terlebih dahulu dilakukan oleh Aparat Pengawasan Intern Pemerintah (APIP). Hasil pengawasan APIP terhadap dugaan penyalahgunaan wewenang berupa tidak terdapat kesalahan, terdapat kesalahan administratif, atau terdapat kesalahan administratif yang menimbulkan kerugian keuangan negara.

Unsur Penyalahgunaan wewenang atau doternement de pouvoir dalam hukum pidana korupsi tidak mempunyai pengertian yang eksplisit yang pada intinya mempertanyakan apakah ada harmoni dan disharmoni antara pengertian yang sama antara hukum pidana, khususnya dengan hukum perdata dan hukum tata usaha Negara sebagai cabang hukum lainnya.

Dalam hal terjadinya kerugian Negara terhadap penyalahgunaan wewenang dalam pengelolaan keuangan daerah haruslah dioptimalkan dalam hal aspek pengawasan. Pengawasan merupakan instrumen utama dalam hukum administrasi yang merupakan bagian dari upaya penegakan hukum preventif. Penegakan hukum sebagai upaya untuk diwujudkannya kepatuhan hukum, dalam konteks hukum administrasi tidak selalu bermakna tindakan responsive dengan diberikan sanksi terhadap pelaku pelanggaran. Aparat pemerintah di tingkat Pusat juga mengambil andil dalam memperbanyak fenomena tersebut. Hal ini tidak terlepas dari kurangnya pengawasan yang semestinya di lakukan oleh pemerintah pusat terhadap penyelenggaraan pemerintah daerah.

Unsur Penyalahgunaan wewenang atau doternement de pouvoir dalam hukum pidana korupsi tidak mempunyai pengertian yang eksplisit yang pada intinya mempertanyakan apakah 
ada harmoni dan disharmoni antara pengertian yang sama antara hukum pidana, khususnya dengan hukum perdata dan hukum tata usaha Negara sebagai cabang hukum lainnya.

Dalam hal terjadinya kerugian Negara terhadap penyalahgunaan wewenang dalam pengelolaan keuangan daerah haruslah dioptimalkan dalam hal aspek pengawasan. Pengawasan merupakan instrumen utama dalam hukum administrasi yang merupakan bagian dari upaya penegakan hukum preventif. Penegakan hukum sebagai upaya untuk diwujudkannya kepatuhan hukum, dalam konteks hukum administrasi tidak selalu bermakna tindakan responsive dengan diberikan sanksi terhadap pelaku pelanggaran.

Melihat dari uraian di atas penulis tertarik untuk menganalisisnya dalam penelitian ini dengan judul " Pengembalian Kerugian Negara akibat Penyalahgunaan Wewenang Terhadap Pengelolaan Keuangan Daerah”.

Berdasarkan uraian latar belakang permasalahan, maka dirumuskan permasalahan yang akan dibahas dalam penelitian ini adalah sebagai berikut:

1. Bagaimanakah bentuk Penyalahgunaan Wewenang Dalam Hukum Administrasi yang mengakibatkan kerugian Negara?.

2. Bagaimanakah Pengaturan Pengembalian Kerugian Negara terhadap Pengelolaan Keuangan Daerah?

\section{TINJAUN PUSTAKA}

\subsection{Pengertian Hukum Keuangan Negara}

Pemahaman terhadap hukum keuangan Negara harus dimulai dengan terlebih dahulu mengetahui pengertian keuangan Negara. terdapat cukup banyak variasi pengertian keuangan Negara, tergantung dari aksentuasi terhadap suatu pokok persoalan dalam pemberian definisi dari para ahli dibidang keuangan Negara. Menurut Pasal 1.1 Undang-undang keuangan Negara: Semua hak dan kewajiban Negara yang dapat dinilai dengan uang serta segala sesuatu, baik berupa uang maupun barang yang dapat dijadikan milik Negara berhubung dengan pelaksanaan hak dan kewajiban tersebut.

Terlihat bahwa definisi keuangan Negara yang sangat luas dikelompokkan menjadi beberapa subbiang, yaitu subbiang pengelolaan fiscal, subbidang pengelolaan moneter, dan subbidang pengelolaanm kekayaan Negara yang dipisahkan.

\subsection{Konsep Kerugian Negara}

Dalam praktek pengelolaan keuangan negara ada beberapa cara terjadinya kerugian negara, yaitu kerugian negara yang terkait dengan berbagai transaksi barang dan jasa, transaksi yang terkait dengan utang-piutang, dan transaksi yang terkait dengan biaya dan pendapatan. Kemungkinan terjadinya kerugian negara tersebut menimbulkan beberapa kemungkinan peristiwa yang dapat merugikan keuangan negara atau perekonomian negara antara lain: Pertama, terdapat pengadaan barang dengan harga yang tidak wajar karena jauh di atas harga pasar, sehingga dapat merugikan keuangan negara sebesar selisih harga pembelian dengan harga pasar atau harga yang wajar. Korupsi di dalam proses pengadaan barang dan jasa inilah yang paling banyak terjadi di Indonesia. Sering proses pengadaan barang dan jasa diikuti dengan adanya suap atau kickback dari peserta tender kepada pejabat negara. Kedua, harga pengadaan barang dan jasa wajar tetapi tidak sesuai dengan spesifikasi barang dan jasa yang dipersyaratkan.

Ketiga, terdapat transaksi yang memperbesar utang negara secara tidak wajar, sehingga dapat dikatakan merugikan keuangan negara karena kewajiban negara untuk membayar hutang semakin besar. 


\section{METODE PENELITIAN}

\subsection{A. Tipe Penelitian}

Dalam penelitian ini, tipe penelitian yang digunakan adalah yuridis normatif. Dipilihnya tipe penelitian ini ditujukan guna mendapat hal-hal yang bersifat teority: prinsip, konsepsi, dokrin hukum, serta isi kaedah hukum yang berhubungan dengan Pengembalian Kerugian Negara Akibat Penyalahgunaan Wewenang terhadap Pengelolaan Keuangan Daerah. Sifat normatif penelitian hukum ini dikaitkan dengan karakter keilmuan hukum itu sendiri.

\section{Pendekatan yang digunakan}

Adapun pendekatan (approach) yang digunakan dalam penelitian ini, dan sesuai dengan rumusan masalah sebagai objek penelitian yang dibahas dan yang akan dijawab, maka pendekatan yang digunakan adalah:

1) Pendekatan konseptual (conceptual approach).

Pendekatan konseptual (conceptual approach) dalam penelitian ini dilakukan dengan peneliti prinsip-prinsip pengembalian Kerugian Negara dalam Hukum Keuangan Negara.

2) Pendekatan perundang-undangan (normatif approach).

Pendekatan perundang-undangan (normatif approach) dilakukan dengan konsep perundang-undangan yang berhubungan dengan Pengembalian Keuangan Negara dalam bentuk hukum positif.

3) Pendekatan sejarah (historical approach).

4) Pendekatan sejarah (historical approach) dalam penelitian ini, dilakukan dengan meneliti sejarah pengaturan Pengembalian Kerugian Negara ditinjau dari beberapa Aspek Peraturan Perundang-undangan.

\section{Pengumpulan Bahan Hukum}

Dalam penelitian ini pengumpulan bahan hukum baik bahan hukum primer maupun bahan hukum sekunder dilakukan dengan cara menggunakan sistem kartu (card system). Digunakan sistem ini adalah untuk mempermudah menganalisis bahan-bahan hukum yang dimaksud.

Bahan-bahan hukum itu meliputi:

1) Bahan Hukum Primer yaitu berupa peraturan perundang-undangan yang berlaku, yang berkaitan dengan permasalahan penelitian ini.

2) Bahan hukum sekunder yaitu bahan hukum yang memberikan penjelasan atas bahan hukum primer yaitu berupa hasil-hasil penelitian yang berhubungan dengan pengaturan pengembalian kerugian negara baik dalam bentuk buku, makalah, textbooks, jurnal, artikel dan internet.

3) Bahan hukum tersier yaitu bahan hukum yang dapat memberikan petunjuk maupun penjelasan terhadap bahan hukum primer dan sekunder berupa kamus hukum dan kamus bahasa Indonesia. 
Analisis bahan hukum dilakukan setelah bahan-bahan hukum terkumpul. Penganalisisan dilakukan terhadap pengertian-pengertian hukum, norma hukum yaitu dengan melihat isi dari berbagai peraturan perundang-undangan yang berhubungan dengan Pengaturan Pengembalian Kerugian Negara Akibat Penyalahgunaan Wewenang terhadap pengelolaan keuangan daerah dalam Penganalisisan juga dilakukan dengan cara interpretasi, evaluasi dan menilai bagaimana pengaturan pengembalian kerugian negara dilihat dari beberapa penerapan hukum.

\section{HASIL DAN LUARAN YANG DIHASILKAN}

\subsection{Bentuk Penyalahgunaan Wewenag dalam Hukum Administrasi Negara yang mengakibatkan Kerugian Negara}

Hukum administrasi dilakukan oleh pemerintah melalui fungsi-fungsi sebagai berikut:

1) Fungsi Normatif (Normatieve functie); fungsi ini mengatur hubungan hukum antara pemerintah dengan rakyat. Bagi pemerintah, hukum administrasi berfungsi untuk menata (regeling) baik organisasi pemerintahan maupun apartanya, memberikan arahan perilaku (normering) menyangkut reksa pemerintahan dan masalah pengayoman. Bagi kewajiban yang menindividual, baik melalui penetapan (bechikkingen) maupun melalui perjanjian (overeenkomsten).

2) Fungsi Instrumental (Instrumentele function); fungsi ini digunakan oleh pemerintah untuk mengarahkan kehidupan rakyat. Secara aktif pemerintah dapat mengarahkan rakyat tersebut melalui peraturan perundang-undangan dan peraturan lainnya, sedangkan secara pasif pengarahan itu diselenggarakan melalui perancangan (planning).

3) Fungsi pengayoman (Waarborg functie); fungsi ini memberikan pengayoman kepada rakyat. Pengayoman yang dimaksudkan adalah pengayoman dibidang reksa pemerintahan, perlindungan hukum, dan masalah ganti rugi. Perlindungan hukum dimaksud adalah bersifat preventif dan represif.

Ketiga fungsi hukum administrasi tersebut saling berkaitan dengan yang lain. Fungsi normatif yang menyangkut penormaan kekuasaan memerintah jelas berkaitan erat dengan fungsi instrumental yang menetapkan instrumen yang digunakan oleh pemerintah untuk menggunakan kekuasaan memerintah dan pada akhirnya norma pemerintahan dan instrumen pemerintahan yang digunakan harus menjamin perlindungan hukum bagi rakyat. ${ }^{\mathrm{vi}}$

Secara umum ada tiga macam perbuatan pemerintahan, yaitu perbuatan pemerintahan dalam bidang pembuatan peraturan perundang-undangan (regeling), perbuatan pemerintahan dalam penerbitan ketetapan (beschikking), dan perbuatan pemerintah dalam bidang keperdataan (meteriele daad). Dua bidang yang pertama terjadi dalam bidang publik sehingga tunduk dan diatur berdasarkan hukum publik, sedangkan yang terakhir khusus dalam bidang perdata, dan karenanya tunduk dan diatur berdasarkan hukum perdata. Atas pembidangan perbuatan pemerintahan ini, Perbuatan melawan hukum oleh pemerintah yang berbentuk melanggar hak subyektif orang lain tidak hanya terbatas pada perbuatan yang bersifat privaatrechtelijk saja, tetapi juga perbuatan yang bersifat publiekrechtelijk.

Timbulnya kerugian yang diderita warga negara dalam penyelenggaraan kenegaraan dan pemerintahan, Menurut Sjachran Basah bahwa: Dapat disebabkan karena dua kemungkinan. Pertama, sikap tindak administrasi negara yang melanggar hukum yaitu pelaksanaan yang salah, padahal hukumnya benar dan berharga. Kedua, sikap tindak administrasi yang menurut hukum, bukan pelaksanaannya yang salah melainkan hukum itu sendiri yang secara materiil tidak benar dan tidak berharga. Kekeliruan dalam pelaksanaan hukum yang benar dan berharga menjadi tanggung jawab administrasi negara, sedangkan hukum yang tidak benar dan tidak berharga menjadi tanggung jawab pembuat hukum, dalam hal ini lembaga legislatif. ${ }^{\text {vii }}$ 
Secara umum dapat dikatakan bahwa ukuran untuk menuntut pemerintah itu bukan ada tidaknya kerugian, tetapi apakah pemerintah itu dalam melaksanakan kegiatannya berdasarkan hukum (rechtmatig) atau melanggar hukum (onrechtmatig) dan apakah perbuatan itu dilakukan untuk kepentingan umum atau bukan. Apabila terhadap semua perbuatan pemerintah atau administrasi negara di bidang publik itu terbuka peluang tuntutan ganti rugi, dalam banyak hal sulit diwujudkan atau dapat dikatakan tidak logis.

Tuntutan diajukan terhadap pemerintah atas segala kerugian harta benda ataupun jiwa seseorang yang diakibatkan oleh kelalaian atau kesalahan dalam berbuat atau tidak berbuat dari pihak pejabat pemerintah yang bertindak dalam rangka tugas atau kewajibannya. Mengukur penyalahgunaan wewenang terutama berkaitan dengan beleidsvrijheid (discretionary power, Freies Ermessen) harus didasarkan pada asas-asas umum pemerintah yang baik, karena asas "wetmatigheid" tidaklah memadai.

Dalam praktek penyelenggaraan pemerintah, asas-asas umum pemerintahan yang baik antara lain meliputi:

1) Larangan sewenang-wenang ( willekeur)

2) Larangan penyalahgunaan wewenang. ${ }^{\text {viii }}$

Terkait dengan parameter penyalahgunaan wewenang dalam kewenangan diskresi parameter yang dipakai adalah asas spesialitas, yang pada dasarnya mengandung tujuan dari suatu wewenang itu diberikan. Terjadinya penyalahgunaan wewenang apabila penggunaan wewenang itu menyimpang dari tujuan. Asas-asas umum pemerintahan yang baik dalam hukum positif Indonesia dapat diketemukan dalam Pasal 53 ayat (2) Undang-Undang nomor 9 Tahun 2004 tentang Peradilan Tata Usaha Negara, yang meliputi:

1) Bertentangan dengan peraturan perundang-undangan;

2) Bertentangan dengan asas-asas umum pemerintahan yang baik.

Asas-asas umum Penyelenggaraan Negara dalam Pasal 3 Undang-Undang Nomor 28 Tahun 1999 Tentang Penyelenggaraan Negara Yang Bersih dan Bebas dari Korupsi, Kolusi, dan Nepotisme meliputi:

1) Asas Kepastian Hukum;

2) Asas Tertib Penyelenggaraan Negara;

3) Asas Kepentingan Umum;

4) Asas Keterbukaan;

5) Asas Proporsionalitas;

6) Asas Profesionalitas;

7) Asas Akuntabilitas.

Dalam perkembangannya Asas-asas Umum Penyelenggaraan Negara dalam UndangUndang 28 Tahun 1999 tersebut diakui dan diterapkan dalam penyelenggaraan pemerintah dan dalam proses peradilan di PTUN. Dalam penyelenggaraan pemerintah dan dalam proses peradilan di PTUN. Pemegang Kekuasaan keuangan Daerah berdasarkan Pasal 283 UndangUndang 23 tahun 2014 Tentang Pemerintahan Daerah:

1) Pengelolaan Keuangan Daerah merupakan bagian yang tidak terpisahkan dari penyelenggaraan Urusan Pemerintahan yang meliputi kewenganan daerah sebagai akibat penyerahan urusan Pemerintahan.

2) Pengelolaan Keuangan Daerah sebagaimana dimaksud pada ayat (1) dilakukan secara tertib, taat pada ketentuan peraturan perundang-undangan, efisien, ekonomis, efektif, transparan, dan bertanggung jawab dengan memperhatikan rasa keadilan, kepatutan dan manfaat untuk masyarakat.

Pasal 284 yaitu:

1) Kepala Daerah adalah pemegang kekuasaan pengelolaan keuangan daerah dan mewakili pemerintah daerah dalam kepemilikan kekayaan daerah yang dipisahkan. 
2) Dalam melaksanakan kekuasaan sebagaimana dimaksud ayat (1), kepala daerah melimpahkan sebagaian atau seluruh kekuasaanya yang berupa perencanaan, pelaksanaan, penatausahaan, pelaporan dan pertanggungjawaban serta pengawasan keuangan daerah kepada pejabat perangkat daerah

3) Pelimpahan sebagaian atau seluruh kekuasaan sebagaimana dimaksud pada ayat (2) didasarkan pada prinsip pemisahan kewenangan antara yang memerintah, menguji dan menerima atau mengeluarkan uang.

Ketentuan Pasal dalam Undang-Undang ini menekankan bahwa yang memiliki kekuasaan dalam pengelolaan keuangan daerah adalah Kepala- Daerah selaku pemimpin pemerintahan daerah. Dalam hal ini Kepala- daerah dapat melimpahkan kepada pejabat lain berdasarkan prinsip pemisahan kekuasaan.

\subsection{Pengaturan Pengembalian Kerugian Negara Terhadap Pengelolaan Keuangan Daerah}

Dasar hukum penyelesaian Kerugian Negara, dalam hal ini tidak terlepas dari ruang lingkup keuangan negara sebagaimana yang diatur dalam:

1) Undang-undang Nomor 17 Tahun 2003 tentang Keuangan Negara. Penyelesaian Kerugian Negara ini diatur mengenai penyelesaian Kerugian Negara terhadap bendahara, pegawai negeri bukan bendahara, dan pada pengelola BUMN. Pada BUMN selalu dikaitkan bersama-bersama dengan BUMD, sebagai bagian dari harta kekayaan negara/daerah yang dipisahkan dari APBN/APBD.

2) Undang-undang Nomor 15 Tahun 2004 tentang Pemeriksaan Pengelolaan dan tanggung Jawab Keuangan Negara.

3) Undang-Undang Nomor 15 Tahun 2006 tentang Badan Pemeriksa Keuangan.

4) Peraturan Badan Pemeriksa Keuangan Nomor 3 Tahun 2007 tentang Tata Cara Penyelesaian Ganti Kerugian Negara terhadap Bendahara.

Siklus pemeriksaan BPK meliputi perencanaan, pelaksanaan dan pelaporan pemeriksaan, serta pemantauan atas pelaksanaan tindak lanjut hasil pemeriksaan. Dalam Pasal 16 UndangUndang Nomor 15 Tahun 2004 mengatur bahwa laporan hasil pemeriksaan atas laporan keuangan pemerintah memuat temuan, kesimpulan dan rekomendasi. Laporan hasil pemeriksaan dengan tujuan tertentu memuat kesimpulan. Laporan hasil pemeriksaan memuat dan melampirkan tanggapan pejabat pemerintah yang bertanggung jawab atas temuan, kesimpulan, dan rekomendasi pemeriksa. ${ }^{\text {ix }}$

Dalam prosedur Hukum Administrasi jangka waktu pengembalian kerugian yang diatur dalam Undang-Undang Nomor 15 tahun 2004, Undang-Undang Nomor 17 tahun 2003 tentang Keuangan Negara, Undang-Undang Nomor 15 Tahun 2006 tentang BPK dan Undang-Undang Nomor 1 Tahun 2004 tentang Perbendaharan Negara. Hanya saja pengaturannya belum begitu jelas dalam setiap peraturan tersebut. Hal tersebut yang membuat rancu dalam pengaturan jangka waktu pengembalian kerugian Negara sebelum proses hukum lain dilaksanakan.

Dalam hal adanya unsur kerugian Negara prosedur awal yang harus dilakukan oleh BPK berdasarkan kewenangannya haruslah adanya temuan dari kerugian Negara yang dimaksud. Adapun temuan pemeriksaan BPK dapat diklasifikasikan menjadi indikasi kerugian Negara/daerah, temuan kekurangan penerimaan, temuan administrasi, temuan kehematan dan efisiensi, dan temuan efektifitas. Hal-hal yang sering muncul dalam temuan pemeriksaan dalam kelima klasifikasi tersebut adalah sebagai berikut:

1) Temuan kerugian/indikasi kerugian Negara/daerah:

(1) pengenaan ganti kerugian Negara (TGR)

(2) tuntutan perbendaharaan 
(3)pemahalan harga (mark up) pengadaan barang/jasa oleh entitas yang berbeda dari penyedia barang yang sama.

(4) kelebihan pembayaran

(5) kekurangan volume pekerjaan

(6) pembayaran honorarium dan atau biaya perjalanan dinas ganda

(7) pengadaan barang/jasa fiktif

(8) barang/jasa yang diterima tidak sesuai dengan kontrak (spesifikasi)

(9) rekanan penyedia barang/jasa wanprestasi

(10) aset dikuasai pihak lain

(11) penggunaan uang/barang untuk kepentingan pribadi

Pasal 4 Undang-undang Nomor 31 Tahun 1999 menegaskan bahwa pengembalian kerugian negara/daerah tidak menghapuskan dipidananya pelaku tindak pidana, hal ini sejalan dengan ketentuan Pasal 64 ayat (2) Undang-undang Nomor 1 Tahun 2004 yang menyatakan "putusan pidana tidak membebaskan dari tuntutan ganti rugi".

Jelaslah pelaku atau penanggung jawab yang mengakibatkan terjadinya kerugian negara/daerah atau perkonomian negara harus dituntut untuk mengembalikan/memulihkan kerugian negara/daerah, baik melalui proses penyelesaian kerugian negara/daerah yang dilaksanakan oleh internal instansi yang anggarannya dirugikan maupun oleh instansi yang khusus memiliki wewenang melakukan penuntutan terhadap penanggung jawab berdasarkan ketentuan yang diatur dalam hukum administrasi negara maupun penuntutan oleh institusi yang memiliki wewenang untuk memproses secara pidana berdasarkan ketentuan yang diatur dalam hukum pidana. ${ }^{\mathrm{x}}$

Berdasarkan ketentuan Pasal 1 angka 22 dan Pasal 59 ayat (2) Undang-undang Nomor 1 Tahun 2004 tentang Perbendaharaan Negara, serta Pasal 1 angka 15 Tahun 2006 tentang BPK, ada 5 (lima) unsur kerugian negara/daerah, yaitu:

1) adanya pelaku/penanggung jawab;

2) Adanya kekurangan uang, surat berharga, dan barang;

3) Adanya kerugian yang jumlahnya nyata dan pasti;

4) Adanya tindakan melanggar hukum atau kelalaian;

5) Adanya kausalitas antara tindakan melawan hukum dengan kerugian yang terjadi. ${ }^{x i}$

Apabila diyakini terdapat unsur kesalahan/kelalaian/perbuatan melawan hukum, pelaku/penanggung jawab yang dapat dimintakan pertanggungjawaban penggantian kerugian negara/daerah dan nilai kerugian negara/daerah yang pasti telah diketahui jumlahnya, maka dapat dilakukan cara penyelesaian sebagai berikut:

1) Diselesaikan secara damai diluar proses penyelesaian kerugian negara/daerah atau melalui pengadilan;

2) Diselesaikan melalui proses penuntutan diluar pengadilan yaitu proses tuntutan perbendaharaan dan tuntutan ganti rugi;

3) Diselesaikan melalui proses peradilan perdata; atau

4) Penagihan oleh instansi yang berwenang dhi. Direktorat Jenderal Kekayaan Negara. ${ }^{\text {xii }}$

\section{KESIMPULAN DAN SARAN}

\subsection{A. Kesimpulan}

Dalam hal untuk menghindari terjadinya kerugian keuangan negara/daerah akibat penyalahgunaan wewenang dalam Hukum Administrasi, tindakan melanggar hukum atau kelalaian seseorang, dalam Undang-undang Perbendaharaan Negara ditegaskan bahwa setiap 
kerugian negara/daerah yang disebabkan oleh tindakan melanggar hukum atau kelalaian seseorang harus diganti oleh pihak yang bersalah. Dengan penyelesaian kerugian tersebut negara/daerah dapat dipulihkan dari kerugian yang telah terjadi.

Penyelesaian kerugian negara/daerah merupakan suatu rangkaian proses pemulihan keuangan negara/daerah, setelah terjadinya kerugian negara/daerah. Proses ini dapat dilakukan melalui mekanisme yang diatur dalam Hukum Adminstrasi Negara berdasarkan UndangUndang di bidang keuangan Negara. Pengenaan pengembalian kerugian negara/daerah terhadap bendahara adalah suatu tata cara perhitungan terhadap bendahara, jika dalam pengurusannya terdapat kekurangan perbendaharaan dan kepada bendahara yang bersangkutan diharuskan mengganti kerugian.

\subsection{Saran}

Diharapkan pengaturan mengenai pengembalian kerugian negara akibat penyalahgunaan wewenang dalam pengelolaan keuangan daerah lebih dipertegas dalam setiap peraturan perundang-undangan yang berkaitan dengan prosedur pengembalian kerugian negara terhadap pengelolaan keuangan daerah yaitu pada Undang-Undang Nomor 17 tahun 2003 tentang Keuangan Negara, Undang-Undang Nomor 15 tahun 2006 tentang Badan Pemeriksa Keuangan dan Undang-Undang Nomor 15 tahun 2004 tentang Pemeriksaan Pengelolaan dan Tanggung Jawab Pengelolaan Keuangan Negara yang sama-sama mengatur mengenai pengembalian kerugian Negara agar tidak menimbulkan penafsiran yang tidak sama terhadap penentuan jangka waktu pengembalian kerugian negara tersebut. Diharapkan Pemerintah segera membuat ketentuan yang konkrit mengenai konsep pengembalian kerugian negara terhadap bendahara dan pegawai negeri bukan bendahara dan Pejabat lain berdasarkan peraturan perundangundangan dan kejelasan kewenangan BPK sebagai pengawas eksternal terhadap pengembalian kerugian negara/daerah agar terciptanya kesatuan pandangan disetiap pengaturan yang berkaitan dengan pengembalian kerugian negara/daerah akibat penyalahgunaan wewenang dalam pengelolaan keuangan daerah.

\section{DAFTAR PUSTAKA}

\section{Buku}

Ahmad Yani,2002,Hubungan Keuangan antara Pemerintah Pusat dan Daerah di Indonesia, Raja Grafindo Persada.

Andrian Sutedi. 2010. Hukum Keuangan Negara. Sinar Grafika, Jakarta

Arifin P. Soeria Atmadja,2009,Keuangan Publik dalam Perspektif Hukum,Rajawali Press,Jakarta

Atep Adya dan BambangT, 2004,Kekuasaan Pengelolaan Keuangan Negara/Daerah;Bwerdasarkan UU Nomor 17 tahun 2003 tentang Keuangan Negara,PT. Elex Media Komputindo,Jakarta.

Badan Pemeriksa Keuangan Republik Indonesia. 2009. Sepintas mengenal BPK Menurut Undang-Undang Di Bidang Keuangan Negara. Ditama binbankum, Jakarta

Bahder Johan Nasution,2008, Metode Penelitian Ilmu Hukum, Mandar Maju, Bandung

Mardiasmo,2004,Otonomi \& Manajemen Keuangan Daerah, Andi,Yogyakarta 
Muchsan, 1992, Sistem Pengawasan terhadap perbuatan Aparat Pemerintah dan Peradilan Tata Usaha Negara di Indonesia,Liberty,Jogjakarta.

Muhammad Djafar Saidi,2011,Hukum Keuangan Negara,RajaGrafindo Persada, Jakarta

Nur Basuki Minarno. 2009. Penyalahgunaan Wewenang dan tindak Pidana korupsi Dalam Pengelolaan keuangan Daerah. Laksbang Mediatama,Surabaya

Ni'matul Huda. 2007. Pengawasan Pusat Terhadap Daerah Dalam Penyelenggaraan Pemerintahan Daerah. FH UII Press, Yogyakarta

Peter Mahmud Marzuki. 2006. Penelitian Hukum. Prenada Media Group, Jakarta.

Philipus M. Hadjon. 1994. Pengantar Hukum Administrasi Indonesia. Gadjah mada University Press, Yogyakarta

-,2004,Discretion Power dan Asas-Asas Umum Pemerintahan Yang Baik, disampaikan pada Semnas " Aspek Pertanggungjawaban Pidana dalam Kebijakan Publik dari Tindak Pidana Korupsi.Semarang

SF.Marbun dan Moh. Mahfud MD,1987,Pokok-Pokok Hukum Administrasi Negara,Liberty, Yogyakarta.

Sukamto Satoto,2004,Pengaturan Eksistensi dan fungsi Badan Kepegawaian Negara,iCV. Hanggar Kreator,Jogjakarta

W. Riawan Tjandra. 2006. Hukum Keuangan Negara. Gramedia Widiasarana Indonesia, Jakarta

\section{Tesis}

Budi Priyono,1999, Tuntutan Perbendaharaan Dan Tuntutan Ganti Rugi Terhadap Pegawai Negeri Sipil Dalam Kasus Korupsi (Studi Tentang Efektifitas Hukum Dalam Pelaksanaan Tindak Pidana Korupsi), Tesis, Jakarta : Program Pasca Sarjana Universitas Jayabaya.

Fitria Nur Aziza.2008. "Penyelesaian Kerugian Terhadap Pengelolaan BUMN". Tesis Magister Hukum Pascasarjana Universitas Indonesia, Jakarta.

\section{Peraturan Perundang-Undangan}

\section{Undang-Undang}

Republik Indonesia, Undang-Undang Dasar Tahun 1945, Sebelum Amandemen.

Republik Indonesia, Undang-Undang Dasar Tahun 1945, Setelah Amandemen.

Republik Indonesia, Undang-undang Nomor 23 tahun 2014 tentang pemerintah daerah.

Republik Indonesia, Undang-undang Nomor 30 tahun 2014 tentang Administrasi Pemerintahan.

Republik Indonesia, Undang-undang nomor 33 tahun 2004 tentang perimbangan keuangan antara pemerintah pusat dengan pemerintah daerah.

Republik Indonesia, Undang-undang Nomor 17 tahun 2003 tentang keuangan Negara.

Republik Indonesia, Undang-Undang Nomor 15 Tahun 2006 tentang Badan Pemeriksa Keuangan 
Republik Indonesia, Undang-Undang Nomor 1 Tahun 2004 tentang Perbendaharaan Negara

Republik Indonesia, Undang-Undang Nomor 15 Tahun 2004 tentang Pemeriksaan Pengelolaan dan Tanggung Jawab Pengelolaan Keuangan Negara

Republik Indonesia, Undang-Undang Nomor 31 Tahun 1999 tentang Pemberantasan Tindak Pidana Korupsi

\section{Peraturan Pemerintah}

Republik Indonesia, Peraturan Pemerintah Nomor 58 Tahun 2005 tentang Pengelolaan Keuangan Daerah

Republik Indonesia, Peraturan Pemerintah Nomor 33 Tahun 2006 tentang Perubahan atas Peraturan Pemerintah Nomor 14 Tahun 2005 tentang Cara penghapusan Piutang Negara/Daerah

Republik Indonesia,Peraturan Pemerintah Nomor 24 tahun 2005 tentang Standar Akuntansi Pemerintahan.

Republik Indonesia, BPK Peraturan BPK Nomor 3 Tahun 2007 tentang Tata Cara Penyelesaian Ganti Kerugian Negara terhadap Bendahara

\section{Footnote}

${ }^{\mathrm{i}}$ M. Djafar Saidi, Hukum Keuangan Negara, Rajawali Pers, Jakarta, 2011, halm. 21.

${ }^{\text {ii } P h i l i p u s ~ M . ~ H a d j o n, ~ P e n g a n t a r ~ H u k u m ~ A d m i n i s t r a s i ~ I n d o n e s i a, ~ G a d j a h M a d a ~ U n i v e r s i t y ~ P r e s s, ~}$ Yogyakarta, 1994, halm. 9-10.

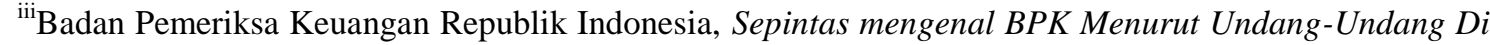
Bidang Keuangan Negara Ditama binbankum, Jakarta, 2009, halm.3.

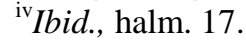

${ }^{v}$ Andrian Sutedi, Hukum Keuangan Negara, Sinar Grafika, Jakarta, 2010, halm. 50.

${ }^{\mathrm{vi}}$ Sukamto Satoto, Pengaturan Eksistensi dan fungsi Badan Kepegawaian Negara,

Kreator, Yogyakarta, 2004, hal. 6.

CV. Hanggar

vii Ibid., hal. 252.

viii Ibid.

ix Ibid., hal. 17.

${ }^{\mathrm{x}}$ Ibid., hal. 2.

xi Ibid., hal. 9.

xii Ibid., hal. 19. 